\title{
Risk assessment of toxic elements in acacia honey
}

\author{
Jelena Ćirićl ${ }^{*}$, Vesna Đorđevićl, Dejana Trbovićl, Tatjana Baltićl , Ivana Branković Lazićl, Kazimir Matović2 \\ Saša Jankovićl, Nenad Parunovićl
}

A b s $t r a c t$ : The element concentrations ( $A s, C u, Z n, F e, C d$ and $\mathrm{Pb}$ ) of 25 acacia honeys from Serbia were analysed using inductively coupled plasma mass spectrometry (ICP-MS). Concerning the toxic element concentrations, all tested honeys met Serbian legislation. Zinc was the major element, ranging between $0.37 \mathrm{mg} \mathrm{kg}^{-1}$ and $3.95 \mathrm{mg} \mathrm{kg}^{-1}$. Positive and significant correlations were found between $\mathrm{Fe}$ and $\mathrm{Cu}(r=0.567)$. This study showed the Serbian honey examined was good quality and met safety criteria concerning concentrations of $\mathrm{As}, \mathrm{Cu}, \mathrm{Zn}, \mathrm{Fe}, \mathrm{Cd}$ and $\mathrm{Pb}$.

Keywords: acacia honey, Serbia, consumption, food safety.

\section{Introduction}

Honey bees and bee products are significant bioindicators of environmental pollution and heavy metals, since bees visit areas of up to $7 \mathrm{~km}^{2}$ (Spiric et al., 2019; Pisani et al., 2008; Rashed et al., 2009; García-Valcárcel et al., 2016; Matin et al., 2016; Ciric et al., 2018). During harvest time, bees are exposed to different sources of contaminants through their pollen and nectar that contains heavy metals of natural and/or anthropogenic origin (Chauzat et al., 2009). Toxic elements are bioaccumulative, and they can be measured in honey bee tissues and bee products (Bogdanov, 2006; Oroian et al., 2016; Gomes et $a l ., 2010)$. On the other hand, many elements have a number of important functions in chemical processes and their fingerprints can be used to determine the botanical and geographic origin of honeys (Erbilir and Erdogrul, 2005). Elements such as $\mathrm{Cu}, \mathrm{Fe}, \mathrm{Mn}, \mathrm{Co}$, $\mathrm{Ni}$ and $\mathrm{Zn}$ are essential elements that have roles in cell metabolism, but in excess amounts, they are harmful. The toxic elements that have negative impact are $\mathrm{Pb}, \mathrm{Cd}, \mathrm{Cr}$ and $\mathrm{Hg} . \mathrm{Pb}$ and $\mathrm{Cd}$ are toxic heavy metals and are, thus, the most frequently studied (Bogdanov et al., 2006). $\mathrm{Pb}$ originating mainly from motor traffic can contaminate air and then directly nectar and honeydew. Generally, $\mathrm{Pb}$ is not transported by plants (Bogdanov et al., 2006). Pb contamination is expected to diminish, due to the increased world-wide use of car-engine catalysts. $\mathrm{Cd}$ originating from the metal industry and incinerators is transported from the soil to plants and can then contaminate nectar and honeydew (Bogdanov et al., 2006). Only a small portion of $\mathrm{Cd}$ might reach honey by air, mainly in the vicinity of incinerators. Also, $\mathrm{Cd}$ and $\mathrm{Pb}$ are environmental pollutants and are used as honey quality indicators.

Serbian honey production, according to Ivanovic et al. (2015), amounts to approximately 4,200 tons in recent years and could potentially be exported to the EU. The most common honeys produced in Serbia are the monoflorals, acacia (Robinia pseudoacacia), linden (Tiliaeuropea) and sunflower (Helianthus annuus), and multifloral honey (Lazarevic et al., 2012; Matovic et al., 2018). So far, existing scientific data on toxic element (As, $\mathrm{Cu}, \mathrm{Zn}, \mathrm{Fe}, \mathrm{Cd}$ and $\mathrm{Pb}$ ) concentrations in honeys from Serbia is very limited. In the present study, the composition of six elements was determined in acacia honey from Serbia. The objectives of this study were to: I) analyse toxic element concentrations and; II) determine potential correlations between some toxic element concentrations in acacia honey.

\section{Materials and methods}

\section{Honey samples}

A total of 25 acacia honeys (collected from different parts of Serbia during the 2018 harvest season) were examined. The botanical origin of the 
Table 1. Quality control of analysis

\begin{tabular}{|c|c|c|c|c|c|}
\hline Elements & $\begin{array}{l}\text { Limit of } \\
\text { detection }\end{array}$ & $\begin{array}{c}\text { Limit of } \\
\text { quantification }\end{array}$ & $\begin{array}{l}\text { Method repeatability/ } \\
\text { precision as RSD (\%) }\end{array}$ & Certified value $^{a}$ & Analysed value \\
\hline As & $\begin{array}{c}\left(\mu \mathrm{g} \mathrm{kg}^{-1}\right) \\
1.2\end{array}$ & $\underset{4}{\left(\mu \mathrm{g} \mathrm{kg}^{-1}\right)}$ & 3.57 & $\begin{array}{l}\left(\mu \mathrm{g} \mathrm{kg}^{-1}\right) \\
19.3 \pm 1.4\end{array}$ & $\begin{array}{l}\left(\mu \mathrm{g} \mathrm{kg}^{-1}\right) \\
20.5 \pm 1.1\end{array}$ \\
\hline $\mathrm{Cu}$ & $\begin{array}{c}\left(\mathrm{mg} \mathrm{kg}^{-1}\right) \\
0.022\end{array}$ & $\begin{array}{l}\left(\mathrm{mg} \mathrm{kg}^{-1}\right) \\
0.066\end{array}$ & 6.26 & $\begin{array}{l}\left(\mathrm{mg} \mathrm{kg}^{-1}\right) \\
275.2 \pm 4.6\end{array}$ & $\begin{array}{l}\left(\mathrm{mg} \mathrm{kg}^{-1}\right) \\
271.9 \pm 5.7\end{array}$ \\
\hline $\mathrm{Zn}$ & $\begin{array}{c}\left(\mathrm{mg} \mathrm{kg}^{-1}\right) \\
0.124\end{array}$ & $\begin{array}{c}\left(\mathrm{mg} \mathrm{kg}^{-1}\right) \\
0.372\end{array}$ & 10.52 & $\begin{array}{l}\left(\mathrm{mg} \mathrm{kg}^{-1}\right) \\
181.1 \pm 1.0\end{array}$ & $\begin{array}{l}\left(\mathrm{mg} \mathrm{kg}^{-1}\right) \\
180.9 \pm 1.8\end{array}$ \\
\hline $\mathrm{Fe}$ & $\begin{array}{c}\left(\mathrm{mg} \mathrm{kg}^{-1}\right) \\
0.08\end{array}$ & $\begin{array}{l}\left(\mathrm{mg} \mathrm{kg}^{-1}\right) \\
0.23\end{array}$ & 4.71 & $\begin{array}{c}\left(\mathrm{mg} \mathrm{kg}^{-1}\right) \\
197.94 \pm 0.65\end{array}$ & $\begin{array}{c}\left(\mathrm{mg} \mathrm{kg}^{-1}\right) \\
197.43 \pm 5.21\end{array}$ \\
\hline $\mathrm{Cd}$ & $\begin{array}{c}\left(\mu \mathrm{g} \mathrm{kg} \mathrm{kg}^{-1}\right) \\
0.4\end{array}$ & $\begin{array}{c}\left(\mu \mathrm{g} \mathrm{kg}^{-1}\right) \\
1\end{array}$ & 8.99 & $\begin{array}{c}\left(\mu \mathrm{g} \mathrm{kg}^{-1}\right) \\
97 \pm 1.4\end{array}$ & $\begin{array}{l}\left(\mu \mathrm{g} \mathrm{kg}^{-1}\right) \\
97.9 \pm 2.6\end{array}$ \\
\hline $\mathrm{Pb}$ & $\begin{array}{l}\left(\mu \mathrm{g} \mathrm{kg}^{-1}\right) \\
2\end{array}$ & $\begin{array}{c}\left(\mu \mathrm{gg}^{-1}\right) \\
3.8\end{array}$ & 3.65 & $\begin{array}{l}\left(\mu \mathrm{g} \mathrm{kg}^{-1}\right) \\
62.8 \pm 1.0\end{array}$ & $\begin{array}{l}\left(\mu \mathrm{g} \mathrm{kg}^{-1}\right) \\
63.3 \pm 2.6\end{array}$ \\
\hline
\end{tabular}

Legend: aCertified value as given by the manufacturer; ${ }^{b}$ Data are mean \pm standard deviation.

honeys was established by information provided by beekeepers. Honeys $(500 \mathrm{~g})$ were stored in glass containers at $4-8^{\circ} \mathrm{C}$ until analysis.

\section{Element concentration analyses}

Approximately $0.5 \mathrm{~g}$ of homogenized honey was transferred into a Teflon vessel with $5 \mathrm{ml} \mathrm{ni-}$ tric acid (67\% Trace Metal Grade, Fisher Scientific, Loughborough, UK) and $1.5 \mathrm{ml}$ hydrogen peroxide $(30 \%$ analytical grade, Sigma-Aldrich, St. Louis, MO, USA) for microwave digestion. The microwave (Start D, Milestone, Sorisole, Italy) programme consisted of three steps: $5 \mathrm{~min}$ from RT to $180^{\circ} \mathrm{C}, 10 \mathrm{~min}$ hold at $180^{\circ} \mathrm{C}$, and $20 \mathrm{~min}$ cooling. After cooling, the digested honeys were quantitatively transferred into disposable flasks and diluted up to $100 \mathrm{ml}$ with deionized water produced by a water purification system (Purelab DV35, ELGA, High Wycombe, Buckinghamshire, UK). Analysis of the following six elements, $\mathrm{As}, \mathrm{Cu}, \mathrm{Zn}, \mathrm{Fe}, \mathrm{Cd}$ and $\mathrm{Pb}$, was performed by inductively coupled plasma mass spectrometry (ICP-MS) (iCap Q mass spectrometer, Thermo Scientific, Bremen, Germany).

Adjustment of physical and electronic parameters was performed before determining the elements, using calibration solution (Thermo Scientific Tune B). The calibration curve consisted of five points in two ranges (including zero). Cadmium and As were measured in the range $0.2-2.0 \mu \mathrm{g} \mathrm{kg}^{-1}$ and $\mathrm{Pb}, \mathrm{Fe}, \mathrm{Cu}$ and $\mathrm{Zn}$ in the range $2.0-20.0 \mu \mathrm{g} \mathrm{kg}^{-1}$. Multielemental internal standard was introduced into the ICP-MS during the measurements. Data analysis software automatically made corrections comparing internal standards. Quality control was performed using certified reference material (CRM) NIST SRM 1577c (Table 1).

\section{Statistical analysis}

Statistical analysis was performed using the GraphPad Prism version 7.00 software. The concentrations of elements in different honey types were expressed as the minimum and maximum, mean \pm standard error (SE) and were subjected to analysis of variance (one-way ANOVA). The parameters were analysed using the Student's t-test at the probability of 0.05 .

\section{Results and discussion}

Toxic element (As, $\mathrm{Cu}, \mathrm{Zn}, \mathrm{Fe}, \mathrm{Cd}$ and $\mathrm{Pb}$ ) concentrations in acacia honey from Serbia are presented in Table 2. The value presented for each element is the average concentration observed. The values of the toxic metals concentrations were compared with those established by the European Union (European Union, 2006) and Serbian legislation (Official Gazette, 2018). The As concentration was $0.004 \mathrm{mg} \mathrm{kg}^{-1}$ in the acacia honey from Serbia. The mean value of As content in honey samples was different in previous studies in Serbia (Spiric et al., 2018), Italy (Pisani et al., 2008), Slovenia (Golob et $a l ., 2005$ ) and New Zealand (Vanhanen et al., 2011). 
Table 2. Mean \pm standard error of the mean, minimum and maximum levels of toxic elements in 25 acacia honeys from Serbia $\left(\mathrm{mg} \mathrm{kg}^{-1}\right)$

\begin{tabular}{ccccc}
\hline Parameter & Mean & SEM & Min & Max \\
\hline $\mathrm{As}$ & 0.004 & - & 0.004 & 0.004 \\
$\mathrm{Cu}$ & 0.147 & 0.0175 & 0.070 & 0.300 \\
$\mathrm{Zn}$ & 1.57 & 0.2398 & 0.370 & 3.950 \\
$\mathrm{Fe}$ & 1.30 & 0.0989 & 0.600 & 2.040 \\
$\mathrm{Cd}$ & 0.003 & 0.00001 & 0.001 & 0.004 \\
$\mathrm{~Pb}$ & 0.004 & 0.00001 & 0.004 & 0.004 \\
\hline
\end{tabular}

As (arsenic) is used industrially as an alloying agent, as well as in the processing of glass, pigments, textiles, paper, metal adhesives, wood preservatives, and ammunition. As is also used in the hide tanning process and, to a limited extent, in pesticides, feed additives, and pharmaceuticals. According to Serbian legislation, the maximum residue limit for As is $0.500 \mathrm{mg} \mathrm{kg}^{-1}$, and all tested samples of acacia honey met this legislation.

The $\mathrm{Cu}$ content ranged between $0.070 \mathrm{mg} \mathrm{kg}^{-1}$ and $0.300 \mathrm{mg} \mathrm{kg}^{-1}$ with an average concentration of $0.15 \mathrm{mg} \mathrm{kg}^{-1}$. In another study of Serbian honey, the $\mathrm{Cu}$ concentration ranged between $94.14 \pm 41.29$ ppb $\left(\mu \mathrm{g} \mathrm{kg}^{-1}\right)$ (acacia) and 737.1 $\pm 470.1 \mathrm{ppb}$ (honeydew) in the 84 tested honeys (Spirić et al., 2018). The $\mathrm{Cu}$ content among honey from different countries ranged widely: $0.25 \mathrm{mg} \mathrm{kg}^{-1}$ in the case of New Zealand honeys (Vanhanen et al., 2011), around 900 $\mu \mathrm{g} \mathrm{kg}^{-1}$ in the case of Italian honeys (Pisani et al., 2008) $0.25-1.10 \mathrm{mg} \mathrm{kg}^{-1}$ in the case of honey from Turkey (Tuzen et al., 2005) and $3.22 \mathrm{mg} \mathrm{kg}^{-1}$ in the case of Slovenian honeys (Golob et al., 2005). Cu can be present in honey due to the copper fungicides used in agriculture. According to Serbian legislation (Official Gazette, 2018), honey should not contain more than $1 \mathrm{mg} \mathrm{kg}^{-1}$ of $\mathrm{Cu}$. The $\mathrm{Cu}$ content ranged between $0.070 \mathrm{mg} \mathrm{kg}^{-1}$ and $0.300 \mathrm{mg} \mathrm{kg}^{-1}$.

The $\mathrm{Zn}$ content in the acacia honeys ranged between $0.37 \mathrm{mg} \mathrm{kg}^{-1}$ and $3.95 \mathrm{mg} \mathrm{kg}^{-1}$. Other literature data showed significant differences in element concentrations between regions in countries or between different honeys in the same regions (Silva et al., 2009). Any increase of $\mathrm{Zn}$ indicates that honey is kept in inadequate packaging or was centrifuged in a galvanized centrifuge (Jevtic et al., 2012). All the investigated acacia honeys met the requirements set by Serbian regulation (Official Gazette, 2018), which require that the $\mathrm{Zn}$ content not exceed $10 \mathrm{mg} \mathrm{kg}^{-1}$.

Fe was the most abundant analysed metal in the examined honeys. The Fe content ranged between $0.600 \mathrm{mg} \mathrm{kg}^{-1}$ and $2.040 \mathrm{mg} \mathrm{kg}^{-1}$, with an average concentration of $1.30 \mathrm{mg} \mathrm{kg}^{-1}$. The Fe content was in the same range as was reported in honeys from Turkey (1.8-10.2 $\mathrm{mg} \mathrm{kg}^{-1}$ ) (Tuzen et al., 2005) and another study of acacia honeys from Serbia (1.19 $\mathrm{mg} \mathrm{kg}^{-1}$ ) (Spiric et al., 2018).

The Cd content ranged between $0.001 \mathrm{mg} \mathrm{kg}^{-1}$ and $0.004 \mathrm{mg} \mathrm{kg}^{-1}$ in acacia honeys from Serbia, with a mean value of $0.003 \mathrm{mg} \mathrm{kg}^{-1}$. The Cd content in honey differs from one country to another; in New

Table 3. Correlation between toxic elements in acacia honey

\begin{tabular}{lllllll}
\hline & As & $\mathbf{C u}$ & $\mathbf{Z n}$ & $\mathbf{F e}$ & $\mathbf{C d}$ & $\mathbf{P b}$ \\
\hline $\mathrm{As}$ & $\mathrm{ns}$ & $\mathrm{ns}$ & $\mathrm{ns}$ & $\mathrm{ns}$ & $\mathrm{ns}$ & $\mathrm{ns}$ \\
$\mathrm{Cu}$ & $\mathrm{ns}$ & $\mathrm{ns}$ & $\mathrm{ns}$ & $0.567^{*}$ & $\mathrm{~ns}$ & $\mathrm{~ns}$ \\
$\mathrm{Zn}$ & $\mathrm{ns}$ & $\mathrm{ns}$ & $\mathrm{ns}$ & $\mathrm{ns}$ & $\mathrm{ns}$ & $\mathrm{ns}$ \\
$\mathrm{Fe}$ & $\mathrm{ns}$ & $0.567^{*}$ & $\mathrm{~ns}$ & $\mathrm{~ns}$ & $\mathrm{~ns}$ & $\mathrm{~ns}$ \\
$\mathrm{Cd}$ & $\mathrm{ns}$ & $\mathrm{ns}$ & $\mathrm{ns}$ & $\mathrm{ns}$ & $\mathrm{ns}$ & $\mathrm{ns}$ \\
$\mathrm{Pb}$ & $\mathrm{ns}$ & $\mathrm{ns}$ & $\mathrm{ns}$ & $\mathrm{ns}$ & $\mathrm{ns}$ & $\mathrm{ns}$ \\
\hline
\end{tabular}

Legend: ${ }^{*} \mathrm{p}<0.05$; ns - not significant, $\mathrm{p}>0.05$ 
Zealand it is $149.0 \mu \mathrm{g} \mathrm{kg}^{-1}$ (Vanhanen et al., 2011), in Italy, $305 \mu \mathrm{g} \mathrm{kg}^{-1}$ (Pisani et al., 2008), in Turkey it ranges between $0.9-17.9 \mu \mathrm{g} \mathrm{kg}^{-1}$ (Tuzen et al., 2005) and in Poland it is $15.0 \mu \mathrm{g} \mathrm{kg}^{-1}$ (Przybytowski et al., 2006).

The mean $\mathrm{Pb}$ content of our acacia honey was $0.004 \mathrm{mg} \mathrm{kg}^{-1}$. Similar results were presented in the study by Spiric et al. (2019). The contamination levels of the toxic elements $\mathrm{Pb}$ and $\mathrm{Cd}$ measured in our study were low and the honeys were safe.

Many previously studies found correlations between toxic element concentrations in honey. Table 3 shows the correlations between toxic element concentrations in the Serbian acacia honeys. There were significant correlations (individual significance level is 0.05 ) only between the levels of $\mathrm{Fe}$ and $\mathrm{Cu}$ $(\mathrm{r}=567)$ in the honeys. Other toxic elements did not correlate significantly $(\mathrm{p}>0.05)$.

\section{Conclusion}

The toxic element concentrations ( $\mathrm{As}, \mathrm{Cu}, \mathrm{Zn}$, $\mathrm{Fe}, \mathrm{Cd}$ and $\mathrm{Pb}$ ) in acacia honey from Serbia were examined, and the levels of $\mathrm{Fe}$ and $\mathrm{Cu}$ correlated. The Serbian honey was of good quality according to national regulation (Official Gazette, 2018). Also, Zn was the major element in the tested honeys, which is in agreement with other honeys around the world.

\title{
Procena rizika toksičnih elemenata u bagremovom medu
}

\author{
Jelena Ćirić, Vesna Đorđević, Dejana Trbović, Tatjana Baltić, Ivana Branković Lazić, Kazimir Matović, \\ Saša Janković, Nenad Parunović
}

A p s tr a kt: Koncentracije elemenata (As, Cu, Zn, Fe, Cd i Pb) u 25 uzoraka bagremovog meda iz Srbije analizirane su primenom ICP-MS. Koncentracija toksičnih elemenata u svim ispitivanih uzorcima meda bila je u skladu sa nacionalnim propisima. Cink je bio glavni element koji se kretao između $0,37 \mathrm{mg} / \mathrm{kg}$ i 3,95 $\mathrm{mg} / \mathrm{kg}$. Utvrđene su pozitivne i značajne korelacije između sadržaja Fe i Cu $(r=0,567)$. Ova studija je pokazala da je bagremov med iz Srbije bio dobrog kvaliteta i ispunio bezbednosne kriterijume za koncentracije $\mathrm{As}, \mathrm{Cu}, \mathrm{Zn}, \mathrm{Fe}, \mathrm{Cd}$ i $\mathrm{Pb}$.

Ključne reči: bagremov med, Srbija, konzumiranje, bezbednost hrane.

Disclosure statement: No potential conflict of interest was reported by authors.

Acknowledgments: This paper was supported by the Ministry of Education, Science and Technological Development, Republic of Serbia, through the funding of the Projects: Selected biological hazards to the safety/ quality of food of animal origin and the control measures from farm to consumer (TR 31034), and; Improvement and development of hygienic and technological procedures in the production of foodstuffs of animal origin in order to obtain quality and safe products that are competitive on the world market (III 46009).

\section{References}

Bogdanov, S. (2006). Contaminants of bee products. Apidologie, 37(1), 1-18.

Chauzat, M. P., Carpentier, P., Martel, A. C., Bougeard, S., Cougoule, N., Porta, P. ... \& Faucon, J. P. (2009). Influence of pesticide residues on honey bee (Hymenoptera apidae) colony health in France. Environmental Entomology, 38(3), 514-523.

Ciric, J., Sando, D., Spiric, D., Janjic, J., Boškovic, M., Glisic, M. \& Baltic, Z. M. (2018). Characterization of Bosnia and Herzegovina honeys according to their physic-chemical properties during 2016-2017. Meat Technology, 59(1), 46-53.
Erbilir, F. \& Erdoĝrul, Ö. (2005). Determination of heavy metals in honey in Kahramanmaraş City, Turkey. Environmental Monitoring and Assessment, 109(1-3), 181-187.

European Union. (2006). Commission Regulation No 1881/2006. EU Legislation Which Sets Maximum Levels for Chemical Contaminants in Foodstuffs.

García-Valcárcel, A. I., Molero, E., Tadeo, J. L., \& Hernando, M. D. (2016). Determination of selected environmental contaminants in foraging honeybees. Talanta, 148, 1-6.

Golob, T., Doberšek, U., Kump, P. \& Nečemer, M. (2005). Determination of trace and minor elements in Slovenian honey by total reflection X-ray fluorescence spectroscopy. Food Chemistry, 91(4), 593-600. 
Gomes, S., Dias, L. G., Moreira, L. L., Rodrigues, P. \& Estevinho, L. (2010). Physicochemical, microbiological and antimicrobial properties of commercial honeys from Portugal. Food and Chemical Toxicology, 48(2), 544-548.

Ivanovic, J., Baltic, M. Z., Jelic, D., Janjic, J., Boskovic, M., Markovic, R. \& Starcevic-Dokmanovic, M. (2015). Research of production volume and market turnover of honey from 2004 to 2014. Veterinarski Glasnik, 69(5-6), 467-478.

Jevtic, G., Andjelkovic, B., Markovic, J., Andjelkovic, S. \& Nedic, N. (2012). Quality of false acacia honey from Rasina district in Serbia. European Hygienic Engineering \& Design Group, 1, 278-283.

Lazarevic, K. B., Andric, F., Trifkovic, J., Tesic, Z. \& Milojkovic-Opsenica, D. (2012). Characterization of Serbian unifloral honeys according to their physicochemical parameters. Food Chemistry, 132(4), 2060-2064.

Matin, G., Kargar, N. \& Buyukisik, H. B. (2016). Bio-monitoring of cadmium, lead, arsenic and mercury in industrial districts of Izmir, Turkey by using honey bees, propolis and pine tree leaves. Ecological Engineering, 90, 331-335.

Matovic, K., Ciric, J., Kaljevic, V., Nedic, N., Jevtic, G., Vaskovic, N. \& Baltic, M. Z. (2018). Physicochemical parameters and microbiological status of honey produced in an urban environment in Serbia. Environmental Science and Pollution Research, 25(14), 14148-14157.

Official Gazette (2018). Regulation on maximum residue limits of plant protection products in food and feed and on food and feed for which maximum residue limits of plant protection products are set (Off. Gazette RS No. 22/18, 90/18 and 76/19).

Oroian, M., Prisacaru, A., Hretcanu, E. C., Stroe, S. G., Leahu, A. \& Buculei, A. (2016). Heavy metals profile in honey as a potential indicator of botanical and geographical origin. International Journal of Food Properties, 19(8), 1825-1836.

Pisani, A., Protano, G. \& Riccobono, F. (2008). Minor and trace elements in different honey types produced in Siena County (Italy). Food Chemistry, 107(4), 1553-1560.

Rashed, M. N., El-Haty, M. T. A. \& Mohamed, S. M. (2009). Bee honey as environmental indicator for pollution with heavy metals. Toxicological and Environmental Chemistry,91(3), 389-403.

Silva, L. R., Videira, R., Monteiro, A. P., Valentão, P., \& Andrade, P. B. (2009). Honey from Luso region (Portugal): Physicochemical characteristics and mineral contents. Microchemical Journal, 93(1), 73-77.

Spiric, D., CiriC, J., Djordjevic, V., Nikolic, D., Jankovic S., Nikolic A., Petrovic, Z., Katanic N. \& Teodorovic V. (2019). Toxic and essential element concentrations in different honey types. International Journal of Environmental Analytical Chemistry.

doi: $10.1080 / 03067319.2019 .1593972$

Vanhanen, L. P., Emmertz, A. \& Savage, G. P. (2011). Mineral analysis of mono-floral New Zealand honey. Food Chemistry, 128(1), 236-240.

Paper received: 27.11.2019.

Paper corrected:.3.12.2019.

Paper accepted: 3.12.2019. 